\title{
EFFECT OF LEAF RUST INFECTION ON YIELD AND TECHNICAL PROPERTIES IN GRAINS OF SOME EGYPTIAN WHEAT CULTIVARS
}

\author{
R.G. Ali ${ }^{(1)}$, R.I. Omara ${ }^{(2)}$ and Zinap A. Ali ${ }^{(1)}$ \\ (1) Food Technology Research Institute, Agricultural Research Center, Giza, Egypt \\ (2) Plant Pathology Research Institute, Agricultural Research Center, Giza, Egypt, \\ redaomara43@yahoo.com
}

Received: May 17, 2016

Accepted: Jun. 15, 2016

\begin{abstract}
Wheat leaf rust disease, caused by Puccinia triticina f. sp. tritici, is one of the most important wheat diseases in Egypt and worldwide. In the present study, Four epidemiological parameters; final rust severity (\%), area under disease progress curve (AUDPC), relative area under disease progress curve (rAUDPC) and rate of disease increase ( $r$-value) and technical properties were estimated for seven Egyptian bread wheat cultivars. The highest percentages of final rust severity (FRS), the highest values of area under disease progress curve (AUDPC), the highest values of relative area under disease progress curve ( $r A \cup D P C)$ and the highest rates of disease increase ( $r$-value) were recorded with the cvs.; Gemmeiza-7, Gemmeiza-11 and Sids-1 during 2014/15 and 2015/16 growing seasons. Accordingly, they recorded high loss (\%) in 1000 kernel weight, yield/feddan and Egyptian pound (LE). There were a positive relations between the four parameters under study and loss (\%) of yield/feddan, where the relation between FRS (\%) and loss (\%) of yield/feddan was the strongest $\left(R^{2}=0.994\right)$. Therefore, the loss $(\%)$ of yield/feddan could be predicted from FRS (\%). Whereas, there were negative relations between FRS (\%) and each of 1000 kernel weight and yield/feddan of the infected wheat cultivars during the two successive seasons. As for, the physical properties, the protected plots of wheat cultivars under study recorded the highest values in the hectoliter and flour extraction comparing to the infected plots of the same cultivars. On the other hand, protein and ash contents increased in the flour of infected wheat cultivars compared with the flour of the same protected ones. Also, farinograph parameters of dough improved slightly for infected cultivars, where values of water absorption and stability time showed little increase, compared with the same protected wheat cultivars. Accordingly, baking quality and sensory of balady bread made from the flour of protected and infected wheat cultivars were slightly increased in layers separation, crumb texture and odor bread. Thus, it could be concluded that the leaf rust infection, negatively affected both grain quality and quantity of wheat cultivars under study.
\end{abstract}

Key words: Wheat, Puccinia triticina, AUDPC, yield losses, physical properties, chemical composition, farinograph parameters, baking quality.

\section{INTRODUCTION}

Wheat (Triticum aestivum L.), more than other cereals, can be expected to assume increasingly greater importance as a source of protein for much of the world's increasing population (El sayed et al., 2007). Even today, wheat provides more nourishment for more people than does any other food source. There are many principle biotic or abiotic factors affecting the yield of wheat crops. The plant fungi are the major biotic stress in reducing the crop yield of wheat cultivars (Bockus et al., 2010). Wheat leaf rust (Puccinia triticina) as a serious foliar disease affecting wheat production, causing great losses in grain yield and affecting grain 
Ali, et al.,

quality. Therefore, it has been considered the main biotic factor that causes not only the high reduction in grain yield, but also it causes a considerable effect on grain quality of the susceptible cultivars (El-Daoudi et al., 1984, Dyck and Lukow 1988 and Mobarak et al., 2010). Under the Egyptian field conditions, leaf rust appears annually on wheat cultivars and causes annual losses in grain yield. Several epidemics of leaf rust on wheat crop have been reported in the past and this disease is continues to be a major threat to future wheat production. Nazim et al. (1983) reported that the losses in grain yield of the susceptible varieties might be exceeded up to $23 \%$ in case of an early onset of leaf rust. While, in Canada, Kolmer (2001) mentioned that the losses due to leaf rust were usually reached to $5 \%-25 \%$ depending on the growth stage of the wheat plants at the time of infection and the susceptibility of the wheat cultivar. Duveiller et al. (2007) showed that the yield losses reached $4 \%$ annually due to leaf rust. As for grain quality, leaf rust reduced the percentage of flour yield and had no other adverse effects on the milling and baking quality (Peturson et al., 1945). Drijepondt et al. (1990) stated that leaf rust infection to the susceptible wheat $\mathrm{cv}$. Thatcher, reduced the total grain yield/plot by $25.4 \%$ and 1000 kernel weight by $15.6 \%$. Also, Thatcher was the highest in the flour protein content but inferior milling, dough development and backing properties. Thus, the challenge now is to produce higher-yielding wheat cultivars with good technological quality, and high level of resistance or tolerance to a wide range of biotic and abiotic stresses.

Accordingly, the wheat leaf rust can create serious disease due to its appearance and prolonged season for its development. Therefore, the best management to control the leaf rust disease is to select the available germplasms against leaf rust infection that showed an adequate level of resistance. This study was carried out to estimate yield losses induced by this disease and to study its effect on grain quality to avoid the future cultivation of cultivars suffering huge yield losses. Furthermore, this study also aimed to help staff of wheat breeding program to select wheat cultivars, characterized by high level of leaf rust resistance, high grain yield components and good technological properties.

\section{MATERIALS AND METHODS 1. Pathological studies}

The present work was carried out at Nubaria Agricultural Research Station, during the growing seasons 2014/2015 and 2015/2016, using 7 Egyptian commercial wheat cultivars i.e. Gemmeiza-7, Gemmeiza-9, Gemmeiza-10, Gemmeiza-11, Sids-1, Sids-12 and Sids-13.

Split plot design with 3 replicates was proposed for this experiment, as the main plots included the tested cultivars. While, the sub-plots were represented by the infected and protected treatments. The experimental unit included 15 rows with $7 \mathrm{~m}$. long and $30 \mathrm{~cm}$. apart. Plot size measured $7 \times 6=42$ $m^{2}$ (1/100 feddan). The experiment was surrounded by a border of highly susceptible wheat varieties i.e. Morocco and Thatcher as a spreader.

Each cultivar was sown under protected conditions by the application of 3 foliar sprays, starting from disease onset and 15 days thereafter. The fungicide Sumi-8 was used in this regard with a rate of $35 \mathrm{~cm}^{3} / 100 \mathrm{~L}$ water. On the other hand, the infected plots were left for natural infection. In addition, the spreader area was artificially inoculated with a mixture of physiological races during the late tillering and late elongation stages.

Disease severity (\%) was recorded four times, 10 days interval, during the growing season, expressed as percentage coverage 
of leaves with rust pustules according to the method adopted by Peterson et al. (1948). Rust reaction was expressed in five infection types (Stakman et al., 1962), i.e. Immune $(0)$, resistant $(R)$, moderately resistant (MR), moderately susceptible (MS) and susceptible (S). The obtained data served in the determination of the final rust severity (FRS \%), as outlined by Das et al. (1993), area under disease progress curve (AUDPC) according to Pandey et al. (1989) and rate of disease increase (r-value) according to Van der Plank (1963). Relative area under disease progress curve (rAUDPC) was estimated according to Milus and Line (1986).

Yield parameters expressed as 1000 kernel weight $(\mathrm{g})$ and grain yield/feddan (ardab) were recorded. Loss (\%) for each cultivar was estimated according the equation of Calpouzos et al. (1976).

Loss $(\%)=(1-\mathrm{Yd} / \mathrm{Yh}) \times 100$

Where:

$\mathrm{Yd}=$ yield of infected or diseased plot.

$\mathrm{Yh}=$ yield of protected plot.

Correlation and regression coefficient "SPSS Regression Modeling" were used to determine the following relationships:-

a. Relationship between FRS (\%), AUDPC, rAUDPC, r-value and loss (\%) of yield/feddan.

b. Relationship between loss (\%) in 1000 kernel weight and loss (\%) in yield/feddan.

c. Relationship between FRS (\%) and each of $1000 \mathrm{kernel}$ weight and yield/feddan of the infected wheat cultivars.

\section{Financial part of the study:}

Data of yield/feddan were converted to $\mathrm{kg} / \mathrm{feddan}$ by multiplying the yield/plot in $4200 \mathrm{~m}^{2}$ (feddan area) and divided by 42 (plot size $=7 \times 6$ ) to obtain the yield of $\mathrm{kg} / \mathrm{feddan}$ after that divided by 150 to obtain the number of ardabs/feddan. Total production value of wheat grain either protected or infected yield for each cultivar was determined and multiplied in the price, since the price of ardab $(150 \mathrm{~kg})=420$ LE. After that, Egyptian pound loss (LE) was estimated by subtracting protected value (LE) from infected one (LE) (Abu El-Naga et al., 1997).

\section{Physical properties of grains}

Hectoliter of each wheat cultivar was determined as described by OGGG (2008).

\subsection{Milling of different Egyptian wheat cultivars}

Egyptian wheat cultivars were cleaned and conditioned at approximately 15\% moisture content. The conditioned wheat cultivars were milled using Qudrumat Senior Laboratory Mill according to AACC (2002).

\subsection{Wet and dry gluten}

Wet and dry gluten percentages were measured according to AOAC (2005).

\subsection{Colour characteristics}

The colour of the flour from different treatments after milling were measured instrumentally using a hand-held Chromameter (model CR-400, Konica Minolta, Japan). The results were expressed in terms of: $L^{*}$ (lightness), $a^{*}$ (rednessgreenness) and $b^{*}$ (yellowness-blueness).

\subsection{Rheological (Farinograph test) \\ properties}

Farinograph test was carried out according to the method described in the AACC (2002) using farinograph set (Brabender Farinograph Germany HZ 50 type 877563) to determine the percent of water absorption of dough, arrival time of dough, dough development time, dough stability time and weakening of dough.

\section{Chemical composition}

Moisture, crude protein, ash and ether extract of wheat flour were determined by 
Ali, et al.,

the standard procedures described in the AOAC (2005). Total carbohydrates were calculated according to the following equation:-

Total carbohydrates $=100-$ (crude protein $\%+$ crude fat $\%+$ ash $\%+$ crude fiber \%).

\section{Preparation of balady bread}

Balady bread from the flour of different wheat cultivars was prepared according to the method of Sallam et al. (1995), in the experimental bakery of Food Technology Research Institute, ARC, Giza, Egypt.

\section{Sensory evaluation of bread}

Bread quality attributes were evaluated after cooling for crust and crumb according the following score in scale; Appearance (15), layers separation (15), crumb texture (15), crust colour (15), taste (20), odor (20) and the overall acceptability (100) were determined according to Faridi and Rubenthaler (1984), with some modifications. Sensory characteristics were judged by ten panelists from the staff members of the Food Technology Research Institute, Agricultural Research Center, Giza, Egypt.

\section{Statistical analysis}

Data were statistically analyzed by the variance and least significant difference (L.S.D) at 5\% levels, according to the method described by McClave and Benson (1991).

\section{RESULTS AND DISCUSSION}

Field reaction of leaf rust (Puccinia triticina) on 7 wheat cultivars was recorded as disease severity (\%), starting from the first rust appearance in each cultivar until dough stage. Four epidemiological parameters; final rust severity (\%), area under disease progress curve (AUDPC), relative area under disease progress curve ( $\mathrm{AUUDPC})$ and rate of disease increase ( $r$ - value) were estimated during the two growing seasons of the study. In season 2014/2015, the obtained results showed that wheat cvs. Gemmeiza-7, Gemmeiza-11 and Sids-1 exhibited high percentages of final rust severity, high values of area under disease progress curve, high values of relative area under disease progress curve (rAUDPC) and high rates of disease increase (r-value). These data were (73.33 $\%, 1250,100.00$ and 0.119$),(60.00 \%$, $1000,80.00$ and 0.101$)$ and $(50.00 \%, 850$, 68.00 and 0.087 ) for the above three cvs., respectively. Whereas, the cvs. Sids-13, Gemmeiza-10, Sids-12 and Gemmeiza-9 exhibited low final rust severity (\%), low values of AUDPC, low values of rAUDPC and low rates of disease increase i.e. (4.33 $\%, 75,6.00$ and 0.008$),(5.00 \%, 107,8.56$ and 0.025$),(6.00 \%, 122,9.76$ and 0.042$)$ and $(8.33 \%, 142,11.36$ and 0.05$)$, respectively (Table 1 and Fig. 1). In season $2015 / 2016$, the results were parallel to those obtained in the previous season (Table 1 and Fig. 1). These results were previously supported by the findings of Nazim et al. (1983) and Nazim et al. (1990) whom found that Giza-155, Giza-157, Giza-164 and Sakha-61 were slightly rusted, showing lower leaf rust severity (\%), under field conditions in Egypt. In this respect, Das et al. (1993) reported that the effective selection for partially resistant genotypes can be practiced in the field, based on the final rust severity (FRS \%), where there was high correlation between FRS (\%) and the parameters used in this study.

In the light of the present study and according to the previous reports, AUDPC is considered a most convenient and a good reliable estimator for indicating the amount of rust infection, occurred during an epidemic in the growing season and equally well measured the expression of leaf rust resistance. Furthermore, AUDPC is considered the result of all factors that influenced disease development, such as differences in environmental conditions, cultivars and population of the pathogen (Nazim et al., 2001; Lal Ahamed et al., 2004, 


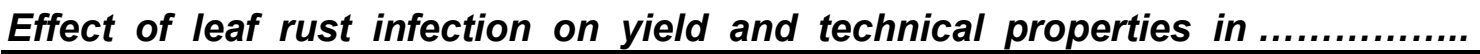

Singh et al., 2005 and Boulot 2007). Therefore, it may be suggested that any cultivar showed AUDPC less than 300 should be having partial resistance (PR) character under field conditions (Singh et al., 1991; Mclntosh, 1991; Knott and Yadan 1993; Hussain et al., 1996; Singh et al., 2004 and Ahmad et al., 2010).

Table (1). Final rust severity (FRS \%), area under disease progress curve (AUDPC), relative area under disease progress curve (rAUDPC) and rate of disease increase (r-value) of seven Egyptian wheat cultivars during 2014/2015 and 2015/16 growing seasons.

\begin{tabular}{lcccc|cccc}
\hline & \multicolumn{7}{c}{ Season/Epidemiological parameters } \\
\cline { 2 - 9 } Cultivar & \multicolumn{7}{c}{ 2014/2015 } & \multicolumn{5}{c}{$2015 / 2016$} \\
\cline { 2 - 8 } & FRS (\%) & AUDPC & rAUDPC & r-value & FRS (\%) & AUDPC & rAUDPC & r-value \\
\hline Gemmeiza-7 & 73.33 & 1250 & 100.00 & 0.119 & 80.00 & 1350 & 100.00 & 0.126 \\
Gemmeiza-9 & 8.33 & 142 & 11.36 & 0.05 & 13.33 & 152 & 11.33 & 0.05 \\
Gemmeiza-10 & 5.00 & 107 & 8.56 & 0.025 & 6.66 & 127 & 9.41 & 0.049 \\
Gemmeiza-11 & 60.00 & 1000 & 80.00 & 0.101 & 73.33 & 1075 & 79.63 & 0.119 \\
Sids-1 & 50.00 & 850 & 68.00 & 0.087 & 63.33 & 925 & 68.52 & 0.112 \\
Sids-12 & 6.00 & 122 & 9.76 & 0.042 & 8.33 & 142 & 10.52 & 0.05 \\
Sids-13 & 4.33 & 75 & 6.00 & 0.008 & 5.00 & 85 & 6.30 & 0.025 \\
\hline LSD $_{0.05}$ & 4.93 & 4.76 & 3.62 & 0.007 & 6.32 & 3.20 & 2.98 & 0.002 \\
\hline
\end{tabular}

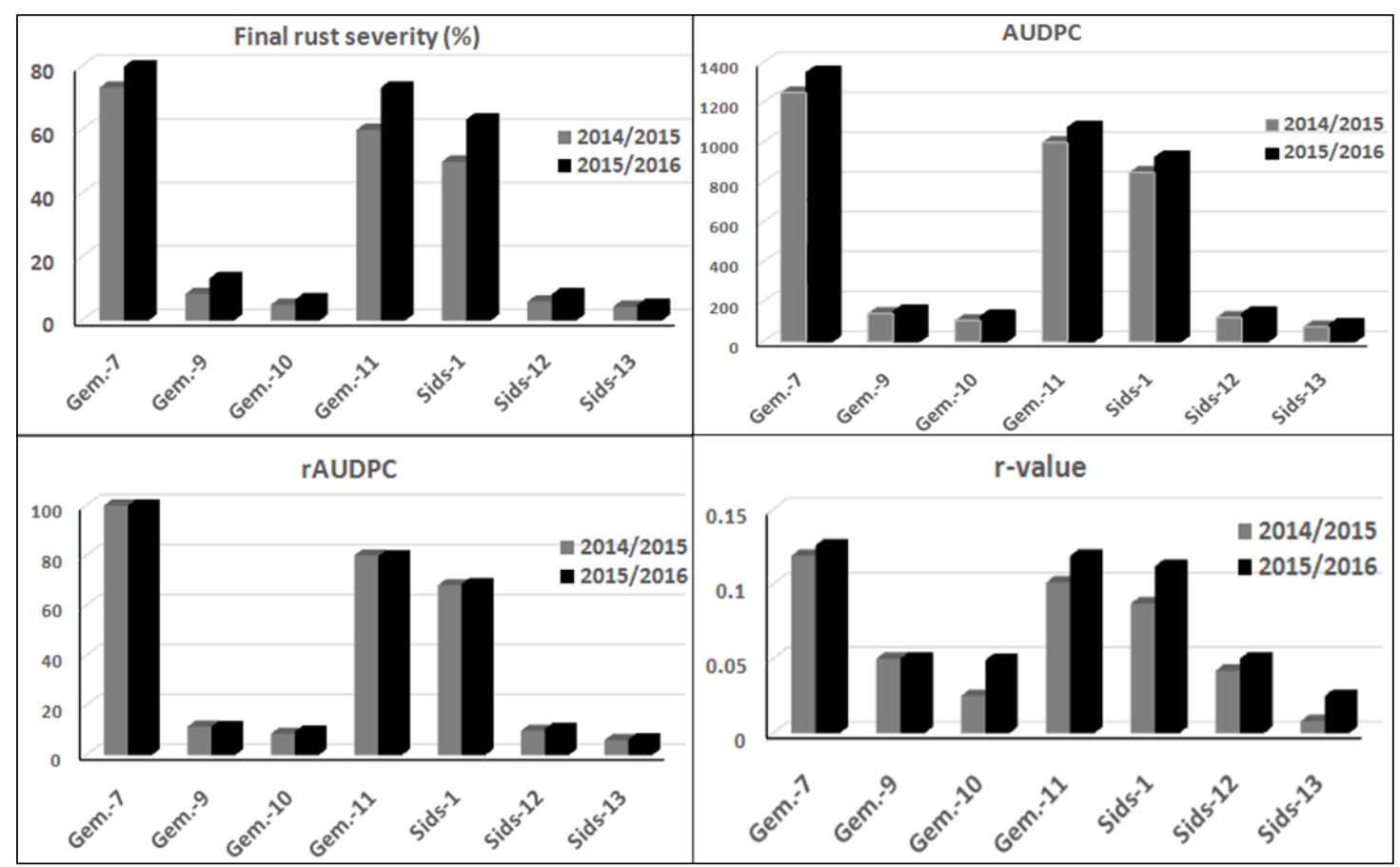

Fig. (1). Final rust severity (\%), area under disease progress curve (AUDPC), relative area under disease progress curve (rAUDPC) and rate of disease increase (r-value) of seven Egyptian wheat cultivars during 2014/2015 and 2015/16 growing seasons. 
Ali, et al.,

In season 2014/2015, the highest loss (\%) of 1000 kernel weight (g) and yield/feddan (ardab) have been recorded with the highly susceptible cultivars Gemmeiza-7 (15.29 and 13.42\%), Gemmeiza-11 (13.40 and 12.25\%) and Sids-1 (12.76 and 10.52\%), respectively. On the other hand, the cultivars i.e. Sids-13 (1.39 and 2.17\%), Gemmeiza-10 (1.86 and $2.61 \%)$, Sids-12 (2.12 and $3.03 \%)$ and Gemmeiza-9 (3.26 and 3.21\%) exhibited the lowest loss (\%) of 1000 kernel weight $(\mathrm{g})$ and yield/feddan (ardab) (Table 2). Accordingly, the highest loss in Egyptian pound (LE) recorded with Gemmeiza-7 (1020.6 LE), Gemmeiza-11 (1121.4 LE) and Sids-1 (840.0 LE), where they obtained high percentages of final rust severity, high values of area under disease progress curve, high values of relative area under disease progress curve and high rates of disease increase (Table 2).

In season 2015/2016, the highest loss (\%) of 1000 kernel weight (g) and yield/feddan (ardab) also recorded with the highly susceptible cultivars Gemmeiza-7
(18.62 and 22.64\%), Gemmeiza-11 (16.96 and $18.60 \%)$ and Sids-1 (14.45 and $16.43 \%)$. On the other hand, the lowest loss (\%) of 1000 kernel weight (g) and yield/feddan (ardab) have been recorded with the partially resistant cultivars Sids-13 (1.65 and 2.40\%), Gemmeiza-10 (2.19 and $2.85 \%)$, Sids-12 (2.47 and $3.60 \%$ ), and Gemmeiza-9 (3.82 and 4.05\%), respectively (Table 3). Therefore, the highest loss of LE recorded with Gemmeiza-7 (1696.8 LE), Gemmeiza-11 (1734.6 LE) and Sids-1 (1214.8 LE) where each obtained high percentage of FRS (\%), high value of AUDPC, high value of rAUDPC and high rate of disease increase ( $r$-value). This loss may be due to the reduction of photosynthesis and collapse of metabolism as a result of disease infection. The previous reports of Putnik-Deliã, (2008) and Omara, (2013) suggested that growing the same cultivar for a long period of time, on a very large area in one region, in addition to the dynamics of pathogen evolution resulted in breakdown its resistance, hence causes high yield loss and affects its grain quality.

Table (2). Loss (\%) of 1000 kernel weight (g), grain yield/feddan (ardab) and Egyptian pound (LE) of seven Egyptian wheat cultivars due to leaf rust infection during 2014/15 growing season.

\begin{tabular}{|c|c|c|c|c|c|c|c|c|c|}
\hline \multirow[b]{2}{*}{ Cultivar } & \multicolumn{3}{|c|}{1000 kernel weight $(\mathrm{g})$} & \multicolumn{3}{|c|}{ Grain yield/feddan (ardab) } & \multicolumn{2}{|c|}{ Production (LE) } & \multirow{2}{*}{$\begin{array}{l}\text { Loss } \\
\text { (LE) }\end{array}$} \\
\hline & Infected & protected & $\begin{array}{c}\text { Loss } \\
(\%)\end{array}$ & Infected & protected & $\begin{array}{l}\text { Loss } \\
(\%)\end{array}$ & Infected & protected & \\
\hline Gem.-7 & 36.00 & 42.50 & 15.29 & 15.67 & 18.10 & 13.42 & 6581.4 & 7602.0 & 1020.6 \\
\hline Gem.-9 & 49.50 & 51.17 & 3.26 & 20.22 & 20.89 & 3.21 & 8492.4 & 8773.8 & 281.4 \\
\hline Gem.-10 & 50.05 & 51.00 & 1.86 & 20.13 & 20.67 & 2.61 & 8454.6 & 8681.4 & 226.8 \\
\hline Gem.-11 & 46.33 & 53.50 & 13.40 & 19.11 & 21.78 & 12.25 & 8026.2 & 9147.6 & 1121.4 \\
\hline Sids- 1 & 43.33 & 49.67 & 12.76 & 17.00 & 19.00 & 10.52 & 7140.0 & 7980.0 & 840.0 \\
\hline Sids-12 & 54.00 & 55.17 & 2.12 & 22.07 & 22.76 & 3.03 & 9269.4 & 9559.2 & 289.8 \\
\hline Sids-13 & 47.33 & 48.00 & 1.39 & 19.78 & 20.22 & 2.17 & 8307.6 & 8492.4 & 184.8 \\
\hline \multicolumn{10}{|l|}{ LSD $_{0.05}$} \\
\hline Cultivars (C) & & 2.08 & & & 1.45 & & & & \\
\hline Treatments $(\mathrm{T})$ & & 1.32 & & & 0.47 & & & & \\
\hline$C \times T$ & & 3.50 & & & 1.25 & & & & \\
\hline
\end{tabular}




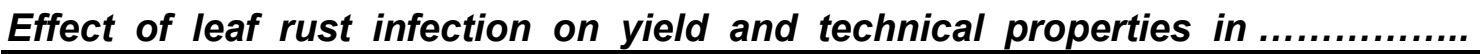

Table (3). Loss (\%) of 1000 kernel weight (g), grain yield/feddan (ardab) and Egyptian pound (LE) of seven Egyptian wheat cultivars due to leaf rust infection during 2015/16 growing season.

\begin{tabular}{|c|c|c|c|c|c|c|c|c|c|}
\hline \multirow{2}{*}{ Cultivar } & \multicolumn{3}{|c|}{1000 kernel weight $(\mathrm{g})$} & \multicolumn{3}{|c|}{$\begin{array}{c}\text { Grain yield/feddan } \\
\text { (ardab) }\end{array}$} & \multicolumn{2}{|c|}{ Production (LE) } & \multirow{2}{*}{$\begin{array}{l}\text { Loss } \\
\text { (LE) }\end{array}$} \\
\hline & Infected & protected & $\begin{array}{l}\text { Loss } \\
(\%)\end{array}$ & Infected & protected & $\begin{array}{l}\text { Loss } \\
(\%)\end{array}$ & Infected & protected & \\
\hline Gem.-7 & 39.33 & 48.33 & 18.62 & 13.80 & 17.84 & 22.64 & 5796.0 & 7492.8 & 1696.8 \\
\hline Gem.-9 & 48.50 & 50.43 & 3.82 & 18.44 & 19.22 & 4.05 & 7744.8 & 8072.4 & 327.6 \\
\hline Gem.-10 & 51.67 & 52.83 & 2.19 & 21.80 & 22.44 & 2.85 & 9156.0 & 9424.8 & 268.8 \\
\hline Gem.-11 & 44.92 & 54.10 & 16.96 & 18.07 & 22.20 & 18.60 & 7589.4 & 9324.0 & 1734.6 \\
\hline Sids- 1 & 41.77 & 48.83 & 14.45 & 14.69 & 17.58 & 16.43 & 6169.8 & 7384.6 & 1214.8 \\
\hline Sids-12 & 52.83 & 54.17 & 2.47 & 21.14 & 21.93 & 3.60 & 8878.8 & 9210.6 & 331.8 \\
\hline Sids-13 & 49.93 & 50.77 & 1.65 & 20.67 & 21.18 & 2.40 & 8681.4 & 8895.6 & 214.2 \\
\hline \multicolumn{10}{|l|}{ LSD $_{0.05}$} \\
\hline Cultivars (C) & & 1.07 & & & 1.12 & & & & \\
\hline Treatments $(\mathrm{T})$ & & 0.57 & & & 0.81 & & & & \\
\hline$C \times T$ & & 1.51 & & & 2.16 & & & & \\
\hline
\end{tabular}

Associations between each of FRS (\%), AUDPC, rAUDPC, r-value and loss (\%) of yield/feddan were determined through regression analysis test, during 2014/15 and 2015/16 growing seasons (Fig. 2 and 3). There were a positive relations between the four parameters under study and loss (\%) of yield/feddan, where estimates of $R^{2}$ were 0.994, 0.992, 0.992 and 0.927 for FRS (\%), AUDPC, rAUDPC, r-value, respectively during the two seasons. Accordingly, the relation between FRS (\%) and loss (\%) of yield/feddan was the strongest $\left(R^{2}=0.994\right)$. Therefore, the loss (\%) of yield/feddan can be predicted from FRS (\%). Also, there was a positive relation between loss (\%) in 1000 kernel weight and loss (\%) in yield/feddan, where $\left(R^{2}=0.993\right)$ during $2014 / 15$ and 2015/16 seasons (Fig. 4). As for, association between FRS (\%) and each of 1000 kernel weight and yield/feddan of the infected wheat cultivars under study, indicated that there were negative relations between them, where estimates of $R^{2}$ were 0.704 and 0.708 in season 2014/15, 0.851 and 0.745 in season 2015/16, respectively (Fig. 5). Accordingly, the loss (\%) in yield/feddan was more stable than the loss (\%) in 1000 kernel weight, during the two growing seasons of the study. These results were in agreement with Ochoa and Parlevliet (2007), whom previously reported that yield loss (\%)was strongly correlated with AUDPC. Also, ElShamy et al. (2011) under the Egyptian conditions, found significant correlation between disease severity (\%) and loss (\%) for 1000-kernel weight and grain yield/plant. 
Ali, et al.,

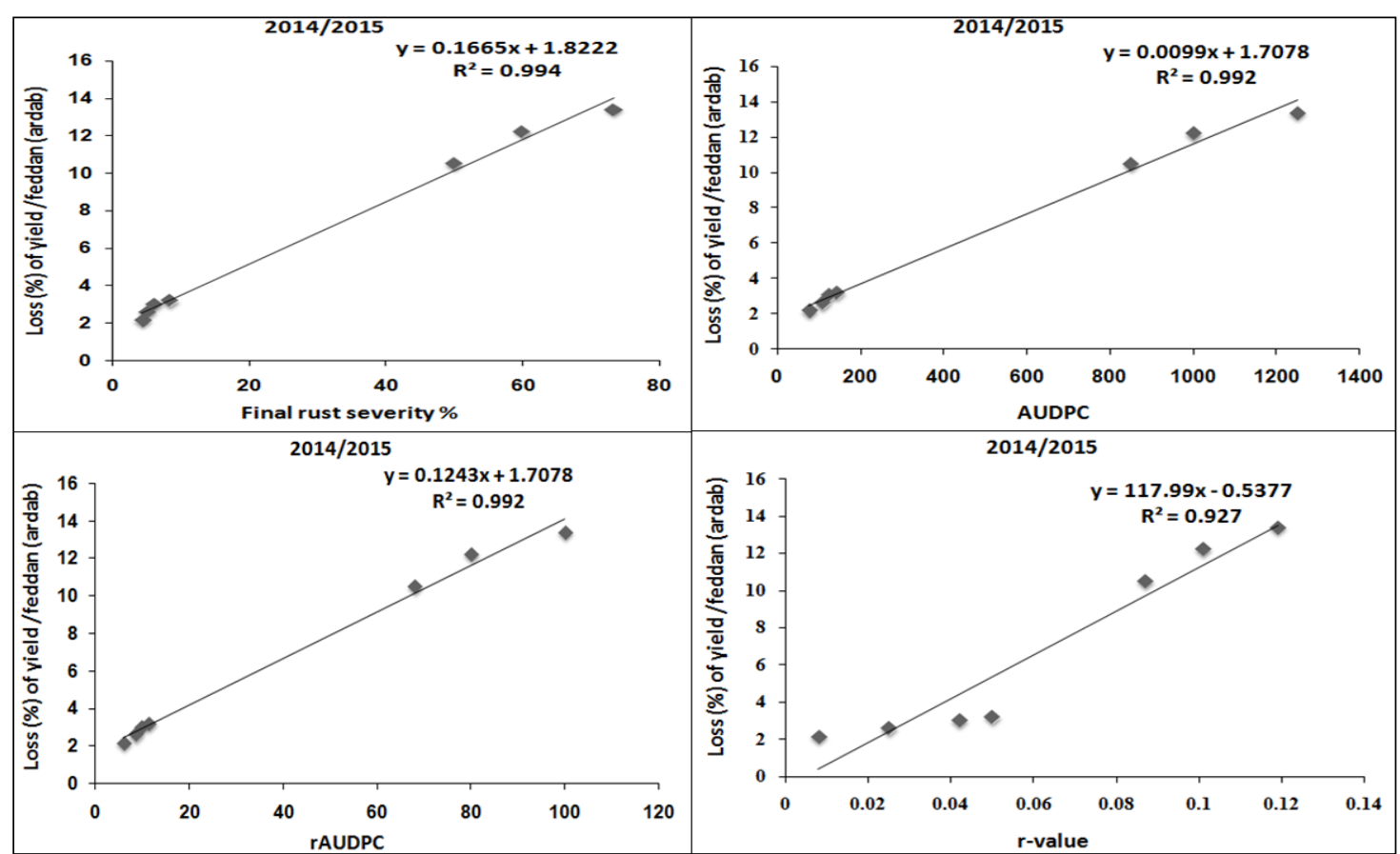

Fig. (2). Relationship between each of FRS (\%), AUDPC, rAUDPC, r-value and yield/feddan (ardab), during 2014/15 growing season.

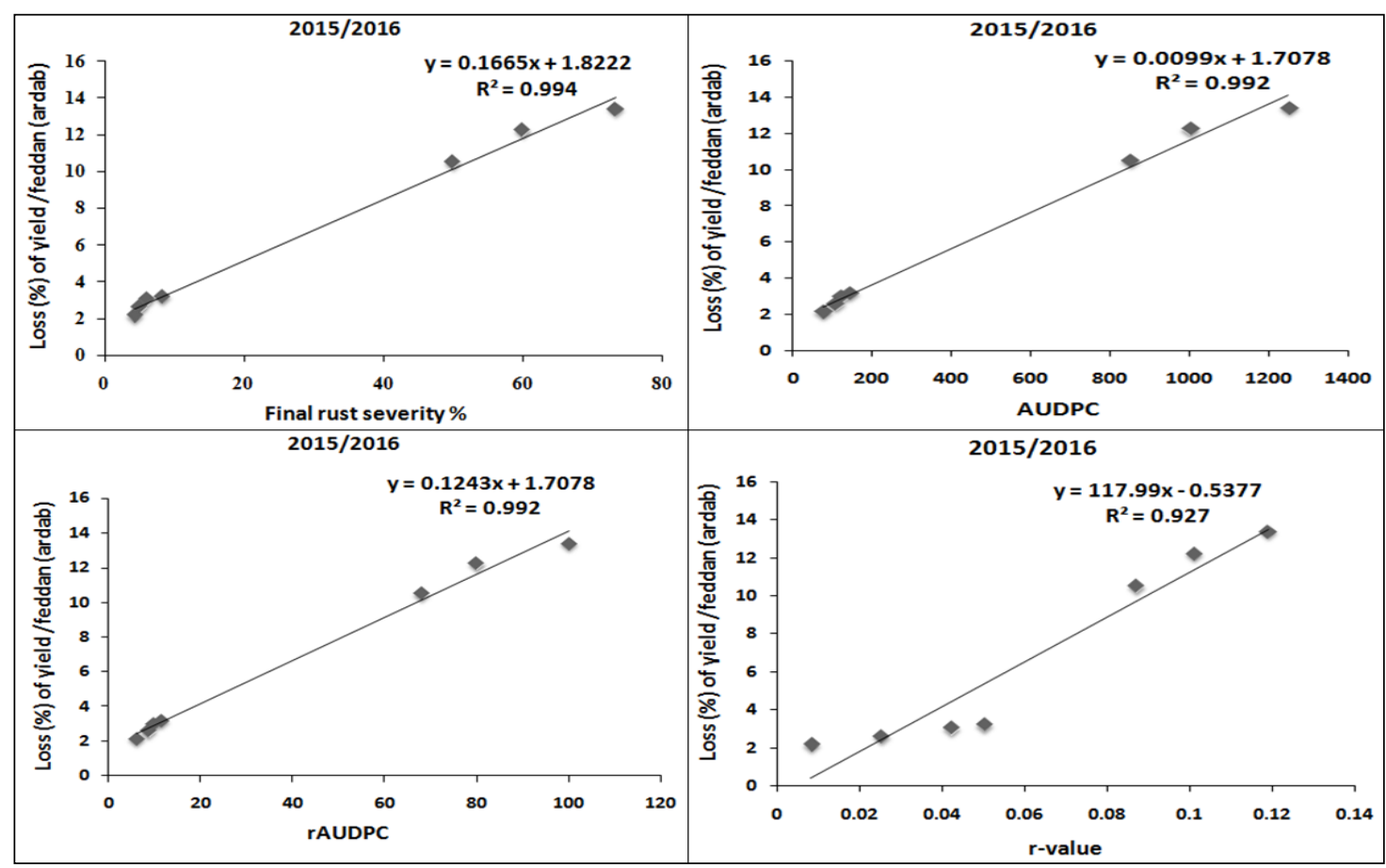

Fig. (3). Relationship between each of FRS (\%), AUDPC, rAUDPC, r-value and yield/feddan (ardab), during 2015/16 growing season. 


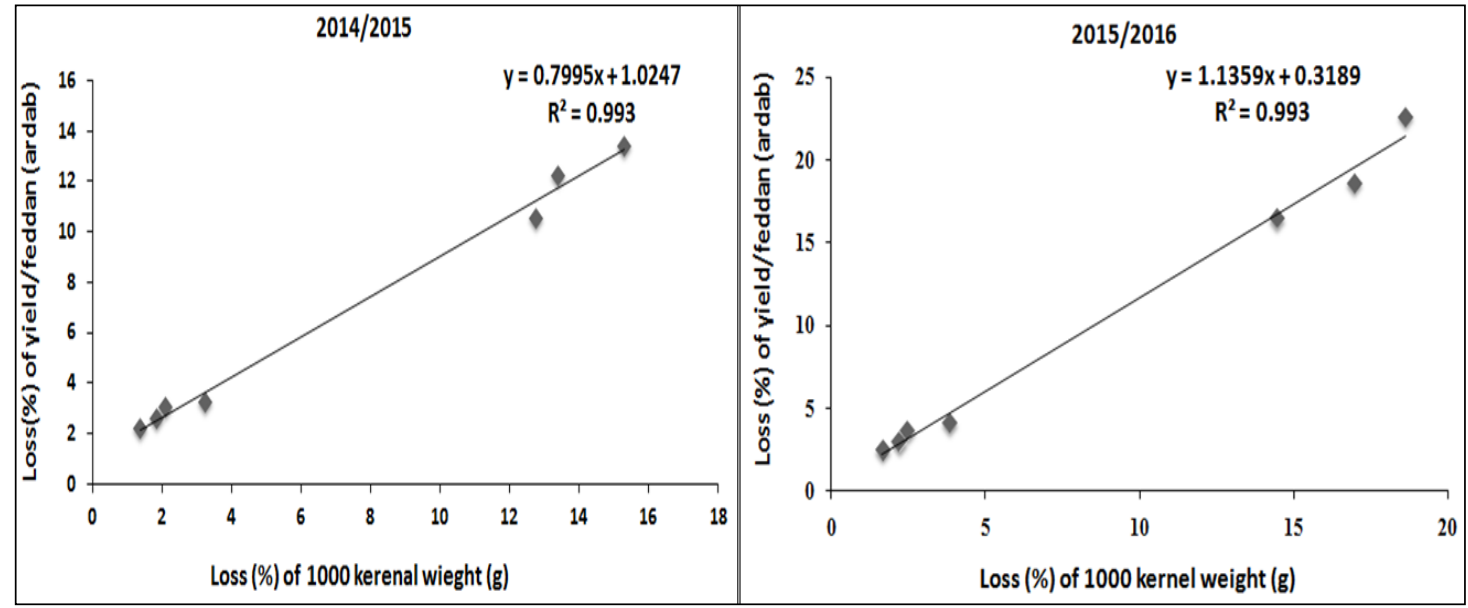

Fig. (4). Relationship between loss (\%) in 1000 kernel weight and loss (\%) in yield/feddan of seven Egyptian wheat cultivars due to leaf rust infection, during 2014/15 and 2015/16 growing seasons.

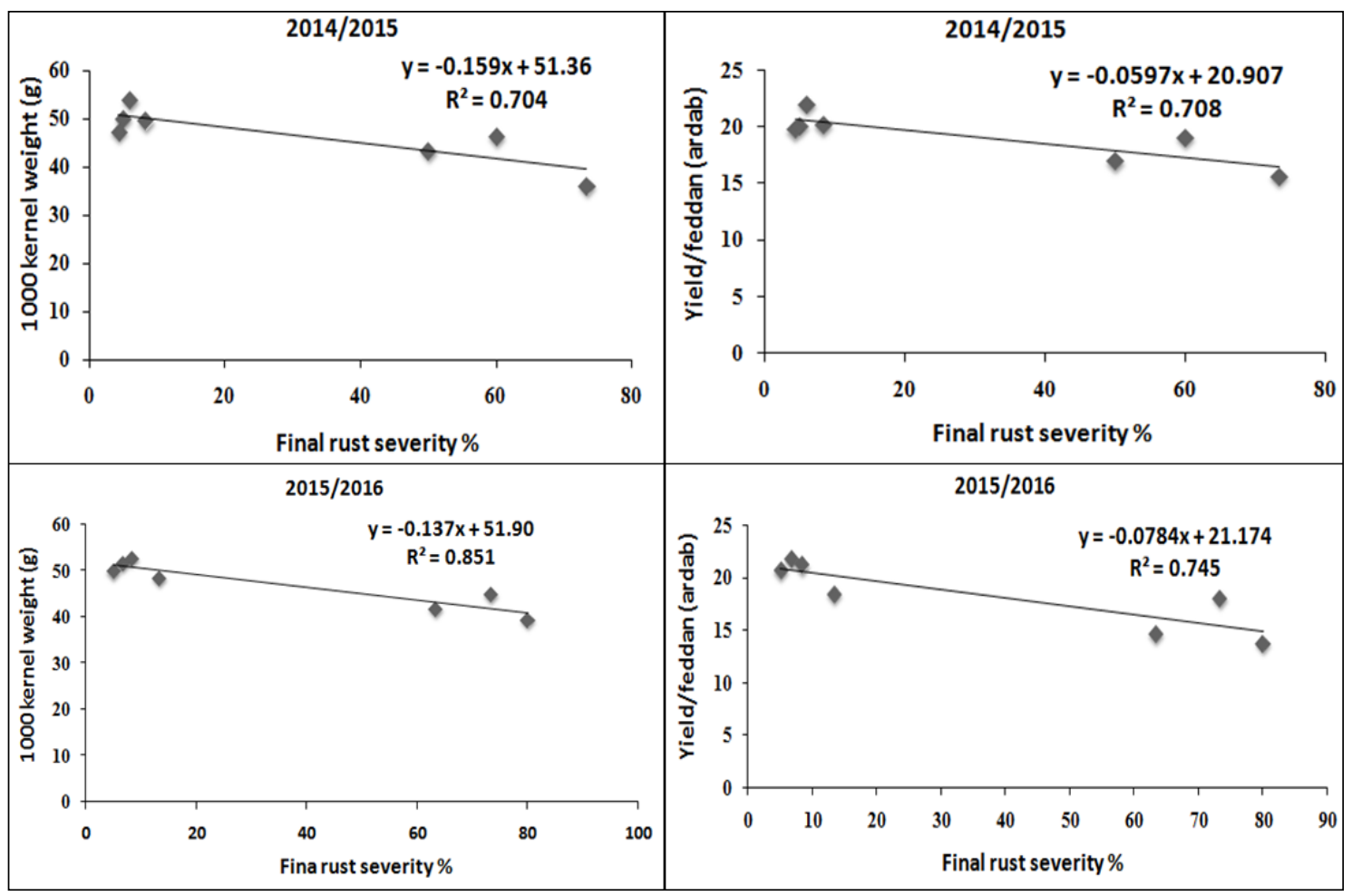

Fig. (5). Relationship between FRS (\%) and each of 1000 kernel weight and yield/feddan of seven Egyptian wheat cultivars infected with leaf rust during 2014/15 and 2015/16 growing seasons. 
Ali, et al.

\section{Physical and milling properties:}

Effect of leaf rust disease on physical and milling properties of grains for seven Egyptian wheat cultivars were shown in Table (4). The highest differences between protected and infected cultivars of Hectoliter weight and Flour (\%) were recorded with the highly susceptible cvs. Gemmeiza-7 (2.42 and 7.24\%), Gemmeiza-11 (0.85 and $5.79 \%)$ and Sids-1 (0.72 and 5.88\%), respectively. While, the least differences were recorded with the partially resistant cultivars Sids-12 (0.24 and 1.40\%), Sids-13 $(0.36$ and $2.85 \%)$, respectively. On the other hand, the infected cultivars recorded higher values than protected with Bran (\%). These results were in agreement with Mousa (2001), who found that the bran weight increased by increasing the disease severity level of leaf rust, and significant difference was found between extraction (\%) of shorts, bran and flour of all varieties used. Similar results previously recorded by Lebedev et al., 1991; Kloppers et al., 1995; Chen et al., 2002 and Wang et al., 2004. It could be concluded that, the infection of leaf rust, mainly decreased the hectoliter weight and flour (\%), compared with the same protected wheat cultivars. This may be due to the shrinking of wheat grains as a result of low moisture and low carbohydrates in flour extraction (Mobarak et al., 2010).

Table (4). Effect of leaf rust infection on physical and milling properties of grains for seven Egyptian wheat cultivars.

\begin{tabular}{|c|c|c|c|c|c|c|c|c|c|}
\hline \multirow{3}{*}{ Cultivar } & \multirow{2}{*}{\multicolumn{3}{|c|}{$\begin{array}{l}\text { Hectoliter weight } \\
\qquad\left(\mathrm{kg} / \mathrm{hl}^{-1}\right)\end{array}$}} & \multicolumn{6}{|c|}{ Milling properties } \\
\hline & & & & \multicolumn{3}{|c|}{ Flour (\%) } & \multicolumn{3}{|c|}{ Bran (\%) } \\
\hline & $I^{*}$ & $\mathrm{P}^{* *}$ & difference & I & $\mathrm{P}$ & difference & 1 & $P$ & difference \\
\hline Gem.-7 & 80.5 & 82.5 & 2.42 & 64 & 69 & 7.24 & 36 & 31 & -16.12 \\
\hline Gem.-9 & 81.0 & 81.5 & 0.61 & 65 & 68 & 4.41 & 35 & 32 & -9.37 \\
\hline Gem.-10 & 81.8 & 82.3 & 0.60 & 65 & 68 & 4.41 & 35 & 32 & -9.37 \\
\hline Gem.-11 & 81.4 & 82.1 & 0.85 & 65 & 69 & 5.79 & 35 & 31 & -12.90 \\
\hline Sids- 1 & 82.5 & 83.1 & 0.72 & 64 & 68 & 5.88 & 36 & 32 & -12.50 \\
\hline Sids-12 & 80.1 & 80.3 & 0.24 & 70 & 71 & 1.40 & 30 & 29 & -3.44 \\
\hline Sids-13 & 82.0 & 82.3 & 0.36 & 68 & 70 & 2.85 & 32 & 30 & -6.66 \\
\hline $\mathrm{LSD}_{0.05}$ & \multicolumn{2}{|c|}{0.61} & & \multicolumn{2}{|c|}{1.22} & \multicolumn{4}{|c|}{0.93} \\
\hline
\end{tabular}




\section{Chemical composition:}

Data presented in Table (5) show chemical properties of wheat flour extracted from protected and leaf rust infected of the same Egyptian wheat cultivars. The values of protein, total carbohydrates, ash, ether extract and crude fiber contents of protected grains ranged from (10.8 - 12.9), (81.6 $83.8),(1.6-2.2),(0.8-1.9)$ and $(1.9-2.9 \%)$, respectively. Meanwhile, the values of protein, total carbohydrates, ash, ether extract and crude fiber contents of the infected one were ranged from (11.2 - 13.6), (80.7 - 83.2), (1.8 - 2.3), (0.7 - 1.7) and (2.1 $3.1 \%$ ), respectively. However, the values of ash and crude fiber of infected wheat grains were slightly higher than protected ones. Also, the flour extracted from infected wheat grains contained higher amount of protein than that of protected wheat grains. As for, protected wheat flour resulted in higher contents of wet and dry gluten compared with that extracted from infected ones. This may be due to the lower extraction rates which reflect the rust consumption of carbohydrates which showed a slight increase of protein. As well these data are in agreement with Ahmed et al. (1995), who found that the resistant wheat varieties were significantly differed in their grain protein contents in comparison with the susceptible ones. Ames et al. (2003) and Edward et al. (2003) reported that protein and gluten contents generally used to assess the quality of wheat flour. They mentioned that, an increase of protein content of grains is accompanied by the increase of gluten strength. Higher protein or very strong gluten results better quality of wheat flour, and plays a significant role in the end product of flour.

Table (5). Effect of wheat leaf rust infection on chemical compositions of grains for seven Egyptian wheat cultivars.

\begin{tabular}{|c|c|c|c|c|c|c|c|c|}
\hline \multirow[b]{2}{*}{ Cultivar } & \multirow[b]{2}{*}{ Treatment } & \multicolumn{7}{|c|}{ Chemical compositions } \\
\hline & & $\begin{array}{c}\text { Protein } \\
(\%)\end{array}$ & $\begin{array}{c}\text { Total } \\
\text { carbohydrates } \\
(\%)\end{array}$ & $\begin{array}{l}\text { Ash } \\
(\%)\end{array}$ & $\begin{array}{l}\text { Ether } \\
\text { extract } \\
(\%)\end{array}$ & $\begin{array}{l}\text { Crude } \\
\text { fiber } \\
(\%)\end{array}$ & $\begin{array}{c}\text { Wet } \\
\text { gluten } \\
(\%)\end{array}$ & $\begin{array}{l}\text { Dry } \\
\text { gluten } \\
(\%)\end{array}$ \\
\hline \multirow{2}{*}{ Gem.-7 } & Infected & 13.6 & 80.7 & 2.1 & 0.7 & 2.9 & 28.1 & 8.90 \\
\hline & Protected & 12.9 & 81.6 & 2.0 & 0.8 & 2.7 & 29.2 & 9.39 \\
\hline \multirow{2}{*}{ Gem.-9 } & Infected & 13.1 & 80.7 & 2.3 & 0.8 & 3.1 & 20.0 & 9.40 \\
\hline & Protected & 12.4 & 81.6 & 2.2 & 0.9 & 2.9 & 20.0 & 9.70 \\
\hline \multirow{2}{*}{ Gem.-10 } & Infected & 12.9 & 81.2 & 2.1 & 0.9 & 2.9 & 28.0 & 9.14 \\
\hline & Protected & 12.2 & 81.9 & 2.0 & 1.1 & 2.8 & 28.2 & 13.00 \\
\hline \multirow{2}{*}{ Gem.-11 } & Infected & 12.8 & 81.8 & 1.9 & 1.2 & 2.3 & 23.6 & 8.06 \\
\hline & Protected & 12.3 & 82.5 & 1.7 & 1.4 & 2.1 & 26.4 & 8.10 \\
\hline \multirow{2}{*}{ Sids-1 } & Infected & 12.4 & 81.8 & 2.1 & 1.7 & 2.4 & 20.0 & 9.78 \\
\hline & Protected & 11.7 & 82.2 & 1.9 & 1.9 & 2.3 & 21.6 & 10.15 \\
\hline \multirow{2}{*}{ Sids-12 } & Infected & 13.3 & 80.9 & 1.8 & 1.6 & 2.4 & 28.2 & 9.90 \\
\hline & Protected & 12.8 & 82.5 & 1.6 & 1.9 & 2.2 & 30.5 & 10.50 \\
\hline \multirow{3}{*}{ Sids-13 } & Infected & 11.2 & 83.2 & 1.9 & 1.5 & 2.1 & 22.1 & 8.10 \\
\hline & Protected & 10.8 & 83.8 & 1.8 & 1.7 & 1.9 & 23.2 & 8.50 \\
\hline & $\mathrm{LSD}_{0.05}$ & 0.30 & 0.32 & 0.15 & 0.17 & 0.32 & 0.65 & 0.32 \\
\hline
\end{tabular}




\section{Farinograph properties and Colour characteristics:}

Data presented in Table (6) show the effect of wheat leaf rust disease on farinograph properties and colour characteristics of wheat flour of grains for seven Egyptian wheat cultivars. Protected cultivars showed the highest values in arrive time ( $\mathrm{min}$ ), development time (min) and degree of weakening, comparing with other infected cultivars, in general. On the other hand, infected cultivars recorded the highest values in water absorption (\%) and stability time ( $\mathrm{min})$, comparing with other protected ones. This may be due to the higher contents of protein quality in infected wheat flour. Cuniberti et al. (2003) reported that, water absorption (\%), correlates well with protein composition. Water absorption is a key parameter for evaluation of wheat cultivars quality. Also, Developing and stability time of the farinograph mainly due to differences in protein quality. These parameters positively correlated with bread baking quality. These data are in agreement with those previously obtained by Uhlen et al. (2004), whom reported that, development time and stability time of farinogram depend on polymeric protein and not on total protein amount in wheat flour. Also, Faubion and Hoseny (1990) stated that, the dough development time (peak time) is an indicator of protein quality, stronger flour normally requires a longer development time than that of weaker flour. As for, the effect of the leaf rust disease in colour characteristics of wheat flour was weak exception L (lightness) where there were differences between protected and infected cultivars which may be due to low extraction rate as shown in Table (6).

Table (6). Effect of wheat leaf rust infection on farinograph properties and colour characteristics of wheat flour of seven Egyptian wheat cultivars.

\begin{tabular}{|c|c|c|c|c|c|c|c|c|c|}
\hline \multirow{2}{*}{ Cultivar } & & \multicolumn{5}{|c|}{ Farinograph properties } & \multicolumn{3}{|c|}{ Colour characteristics } \\
\hline & & $\begin{array}{c}\text { Water } \\
\text { absorption } \\
(\%)\end{array}$ & $\begin{array}{c}\text { Arrival } \\
\text { time } \\
\text { (min) }\end{array}$ & $\begin{array}{l}\text { Development } \\
\text { time (min) }\end{array}$ & $\begin{array}{c}\text { Stability } \\
\text { time } \\
(\mathrm{min})\end{array}$ & $\begin{array}{c}\text { Degree of } \\
\text { weakening } \\
(B . U)^{*}\end{array}$ & $\mathrm{~L}^{3}$ & $a^{4}$ & $b^{5}$ \\
\hline \multirow[b]{2}{*}{ Gem.-7 } & $1^{1}$ & 64.6 & 1 & 1 & 4.5 & 90 & 73.44 & -0.14 & 9.22 \\
\hline & $P^{2}$ & 62.4 & 1.5 & 1.5 & 3.5 & 100 & 75.90 & -0.19 & 10.33 \\
\hline \multirow{2}{*}{ Gem.-9 } & 1 & 61.7 & 1 & 1.5 & 4.5 & 80 & 85.60 & -0.20 & 8.55 \\
\hline & $P$ & 61.4 & 1.5 & 1.5 & 4 & 110 & 76.71 & -0.18 & 7.88 \\
\hline \multirow{2}{*}{ Gem.-10 } & 1 & 64.3 & 1.5 & 2 & 5.5 & 70 & 76.90 & -0.60 & 11.40 \\
\hline & $\mathrm{P}$ & 63.3 & 2 & 1.5 & 4.5 & 100 & 68.96 & 0.13 & 11.19 \\
\hline \multirow{2}{*}{ Gem.-11 } & I & 60.6 & 1 & 1 & 3.5 & 90 & 67.43 & -0.03 & 6.96 \\
\hline & $\mathrm{P}$ & 59.9 & 1.5 & 1.5 & 3 & 120 & 70.53 & -0.14 & 6.75 \\
\hline \multirow{2}{*}{ Sids- 1} & 1 & 63.8 & 1 & 1 & 5 & 100 & 73.44 & 0.67 & 6.91 \\
\hline & $\mathrm{P}$ & 63.2 & 1.5 & 1.5 & 4 & 110 & 68.83 & 0.44 & 6.86 \\
\hline \multirow[t]{2}{*}{ Sids-12 } & 1 & 66.4 & 1 & 1 & 5.5 & 110 & 71.44 & 0.69 & 6.94 \\
\hline & $\mathrm{P}$ & 66.1 & 1.5 & 1.5 & 4.5 & 140 & 68.83 & 0.45 & 6.88 \\
\hline \multirow[t]{2}{*}{ Sids-13 } & 1 & 67.5 & 1.5 & 2.5 & 6 & 80 & 89.92 & -.072 & 15.51 \\
\hline & $\mathrm{P}$ & 67.4 & 2 & 1.5 & 5.5 & 130 & 88.72 & .17 & 15.06 \\
\hline \multicolumn{2}{|c|}{ LSD $_{0.05}$} & 0.44 & 0.33 & 0.36 & 0.74 & 3.28 & 1.53 & 0.04 & 0.76 \\
\hline
\end{tabular}




\section{Sensory properties of balady bread:}

Data presented in Table (7) show sensory properties of balady bread produced from wheat flour protected and leaf rust infected grains. Sensory properties values of layers separation, crumb texture and odor of bread wheat produced from infected wheat, showed good quality compared with bread produced from protected wheat flour. This may be due to the increment of proteins in infected wheat flour rather than those in protected ones. These results are in agreement with Drijepondt et al. (1990), whom stated that the susceptible variety Thatcher was the highest in flour protein content, but inferior milling, dough development and backing properties. Uheln et al. (2004) reported that, the differences in baking quality related to differences in gluten protein composition and in particular to high molecular weight gluten in subunits, which are essential for mixing requirements and resistance of the dough. Also, they reported that increased protein content however, generally increased dough extensibility. Therefore it could be concluded that protein content and protein quality have major influences on the baking potential of wheat flour.

Table (7). Sensory properties of balady bread, produced from wheat flour of seven Egyptian wheat cultivars protected and infected wheat.

\begin{tabular}{|c|c|c|c|c|c|c|c|c|}
\hline \multirow[b]{2}{*}{ Cultivar } & & \multicolumn{7}{|c|}{ Sensory properties } \\
\hline & & $\begin{array}{c}\text { Appearance } \\
\text { (15) }\end{array}$ & $\begin{array}{l}\text { Layers } \\
\text { separation } \\
(15)\end{array}$ & $\begin{array}{c}\text { Crumb } \\
\text { texture } \\
(15)\end{array}$ & $\begin{array}{l}\text { Crust } \\
\text { color } \\
(15)\end{array}$ & $\begin{array}{c}\text { Taste } \\
(20)\end{array}$ & $\begin{array}{l}\text { Odor } \\
\text { (20) }\end{array}$ & $\begin{array}{l}\text { Overall } \\
\text { acceptability } \\
(100)\end{array}$ \\
\hline \multirow{2}{*}{ Gem.-7 } & $I^{*}$ & 13.6 & 13.5 & 13.8 & 13.6 & 17.3 & 17.2 & 88.52 \\
\hline & $P^{* *}$ & 14.5 & 13 & 13.5 & 14 & 18 & 17 & 90.21 \\
\hline \multirow{2}{*}{ Gem.-9 } & 1 & 14 & 13.5 & 13.3 & 13.4 & 17.4 & 17.2 & 88.54 \\
\hline & $P$ & 13.3 & 13.2 & 13.2 & 13.7 & 17.6 & 17.5 & 88.24 \\
\hline \multirow{2}{*}{ Gem.-10 } & 1 & 13.8 & 13.3 & 13.3 & 13.6 & 17.6 & 17.3 & 88.64 \\
\hline & $P$ & 13.4 & 13.5 & 13.2 & 13.4 & 17.6 & 17.2 & 88.12 \\
\hline \multirow{2}{*}{ Gem.-11 } & I & 13.6 & 13.6 & 13.5 & 13.6 & 17.5 & 17.4 & 89.05 \\
\hline & $P$ & 13.6 & 13.4 & 13.3 & 13.4 & 17.5 & 17.2 & 88.34 \\
\hline \multirow{2}{*}{ Sids-1 } & I & 13.8 & 13.4 & 13.2 & 13.3 & 17.0 & 17.5 & 88.05 \\
\hline & $P$ & 13.6 & 13.3 & 13.1 & 13.5 & 17.8 & 17.4 & 88.30 \\
\hline \multirow{2}{*}{ Sids-12 } & I & 13.5 & 13.4 & 13.1 & 13.5 & 17.5 & 17.5 & 88.14 \\
\hline & $P$ & 13.2 & 13.3 & 13.3 & 13.8 & 17.6 & 17.2 & 88.21 \\
\hline \multirow{2}{*}{ Sids-13 } & I & 13.7 & 13.5 & 13.4 & 13.9 & 17.4 & 16.6 & 88.10 \\
\hline & $P$ & 13.6 & 13.4 & 13.3 & 13.6 & 17.7 & 17.4 & 89.05 \\
\hline \multicolumn{2}{|c|}{$\mathrm{LSD}_{0.05}$} & 0.51 & 0.47 & 0.57 & 0.54 & 0.42 & 0.54 & 0.84 \\
\hline
\end{tabular}

I = Infected and $\mathrm{P}^{\prime \prime}=$ Protected 


\section{REFERENCES}

AACC. (2002). American Association of Cereal Chemists, Methods 54-21, In Approved Methods of The American Association of Cereal Chemist, The Association, St., Paul, MN., USA.

Abu El-Naga, S.A., M.M. Khalifa, W.A. Youssef, I.A. Imbaby, M.M. EL-Shamy, E. Amer and T.M. Shehab El-Din (1997). Effect of stripe rust infection on grain yield in certain wheat cultivars and the economic threshold of chemical control application in Egypt during 1996/1997 growing season. National Annual Coordination Meeting, NVRSRP/Egypt Sept., 11-15:81-90.

Ahmad, S., M.A. Khan, M.M. Haider, Z. lqbal, Y. Iftikhar and M. Hussain (2010). Comparison of yield losses in different wheat varieties/lines due to leaf rust disease. Pak. J. Phytopathol., 22(1):1315.

Ahmed, M.I., Y. Yusuf and H.A. Ali (1995). Differences in protein content in levels of resistant and susceptible varieties of wheat (Triticum aestivum) after infection with brown rust fungus (Puccinia recondita). Pakistan J. Botany, 17(1):187191.

Ames, N.P., J.M. Clarke, J.E. Dexter, S.M. Woods, F. Selles and B. Marchylo (2003). Effect of Nitrogen fertilizer on protein quality and gluten strength parameter in durum wheat varieties (Triticum turgidum L.) of the variable gluten strength. Cereal Chem., 80(2): 203-211.

AOAC. (2005). Official Methods of Analysis of the Association of Official Analytical Chemists. Arlington, Virginia, USA.

Bockus, W., R.L. Bowden, R.M. Hunger, W.L. Morill, T.D. Murray and R.W. Smiley (2010). Compendium of wheat diseases and pests. APS Press, St. Paul, Minnesota, Pp. 171.
Boulot, O.A. (2007). Durable resistance for leaf rust in twelve Egyptian wheat varieties. Egypt. J. Appl. Sci., 7:40-60.

Calpouzos, L., A.P. Roelfs, M.E. Maolison, F.B. Martin, J.R. Welsh and R.D. Wilcoxson (1976). A new model to measure yield losses caused by stem rust in spring wheat. Minn. Agric. Exp. Stn. Tech. Bull., 307:1-23.

Chen, X., M. Moore, E.A. Ailus, D.L. Long, R.F. Line, D. Marshall and L. Jackson (2002). Wheat stripe rust and races of Puccinia Striiformis $\mathrm{f} \mathrm{sp}$. tritici in the United States in 2000. Plant Dis., 86(1):39-46.

Cuniberti, M.B., M.R. Roth and F. Mac Ritchie (2003). Protein compositionfunctionality relationship for a set of Argentinean wheats. Cereal Chem., 80(2):132-134.

Das, M.K., S. Rajaram, W.K. Ktonstad, C.C. Mundt and R.P. Singh (1993). Association and genetics of three components of slow rusting in leaf rust of wheat. Euphytica, 68:99-109.

Drijepondt, S.C., Z.A. Pretorius, D. Van Lill and F.H.J. Rijkenberg (1990). Effect of Lr34 resistance on leaf rust development, grain yield and backing quality in wheat. Plant Breeding, 105(1):62-68.

Duveiller, E., R. Singh and J. Nicol (2007). The challenges of maintaining wheat productivity: pests, diseases, and potential epidemics. Euphytica, 157:417430.

Dyck, P.I. and O.M. Lukow (1988). The genetic analysis of two interspecific sources of leaf rust resistance and their effect on quality of common wheat. Can. J. Plant Sci., 68:633-639.

Edwards, N.M., S.J. Mulvaney, M.G. Scanlon and J.E. Dexter (2003). A role of gluten and its components in determining durum semolina dough viscoelastic properties. Cereal Chem., 80(6):755-763. 
El sayed, E.A., A.K. Mostafa and E.M. ElBeially (2007). Genetic studies in some bread wheat crosses. Egyptian J. Agric. Res., 85(3):925- 939.

El-Daoudi, Y.H., Nawal A. Abdel-Hamid and Nabila El-Sherif (1984). Effect of leaf rust infection on yield and seed quality of two wheat varieties. Agric. Res. Center, 62:33-39.

El-Shamy, M.M., Minaas, A. Sallam and M.H. Abd El-Kader (2011). Effect of sowing density of some susceptible bread wheat cultivars on tolerance to leaf rust disease. Zagazig J. Agric. Res., 38:339352.

Faridi, H. and G. Rubenthaler (1984). Effect of baking time and temperature on bread quality, starch gelatinization and staling of Egyptian balady bread. J. Cereal Chem., 61(2):151.

Faubion, J.M. and R.C. Hoseny (1990). The viscoelastic properties of wheat flour doughs. Chap. 2 in: Dough Rheology and Baked Product Texture. H. Faridi, and J. M. Faubion eds. AVI Publishing: New York.

Hussain, M., H. Mumtaz and J.A. Shah (1996). Wheat rust scenario in 19941995. Pak. J. Phytopathol., 8:96-100.

Kloppers, F.J., Z.A. Pretorius and D. Van Lill (1995). Field evaluation of leaf rust severity, yield loss and quality characteristics in near-isogenic wheat lines with Lr29, Lr35 or Lr37. South African J. Plant and Soil, 12(2):55-58.

Knott, D.R. and B. Yadan (1993). The mechanism and inheritance of adult plant leaf rust resistance in the 12 wheat lines. Genome, 36:877-883.

Kolmer, J.A. (2001). Physiologic specialization of Puccinia triticina in Canada in 1998. Plant Dis., 85:155-158.

Lal Ahamed, M., S.S. Singh, J.B. Sharma and R.B. Ram (2004). Evaluation of inheritance to leaf rust in wheat using area under disease progress curve. Hereditas, 141(3):323-327.
Lebedev, V.B., A.V. Vsil and E.V. Yakubova (1991). Estimation of spring wheat possible loss due to brown rust. Soviet Agric. Sciences, 1:14-17.

McClave, J. and G. Benson (1991). Statistics for business and economics. Dellen Publishing, Fifth Edition. San Francisco, USA.

Mclntosh, R.A. (1991). Alien sources of disease resistance in bread wheat. In: Sasakuma, T., Kinoshita, T. (Eds.), Proc. of Dr. H. Kihara Memorial Int. Symp. on Cytoplasmic Engineering in Wheat: Nuclear Organ GenomesWheat Species. Kihara Institute for Biological Research, Yokohama City University, Yokohama, pp. 320-332.

Milus, E.A. and R.F. Line (1986). Gene action for inheritance of durable, hightemperature, adult plant resistances to stripe rust in wheat. Phytopathol., 76:435441.

Mobarak, El.A., R.I. Omara and M.A. Najeeb (2010). Effect of susceptibility of some Egyptian wheat cultivars to stripe rust infection on physical, chemical and technological properties. J. Agric. Sci. Mansoura Univ., 1(6):375-385.

Mousa, M.M.A. (2001). Studies on Yield Losses and the Economic Threshold of Leaf Rust on Some Wheat Cultivars in Egypt". Ph.D. Thesis, Plant Pathol., Minufiya Univ., 203p .

Nazim, M., A.A. El-Shehidi, Y.A. Abdou and Y.H. El-Daoudi (1983). Yield loss caused by leaf rust on four wheat cultivars under epiphytotic levels. $4^{\text {th }}$ Confer. Microbiol., Cairo, 17-27.

Nazim, M., M.Z. El-Shanawani, Z. ElShennawy and O.A. Boulot (1990). Partial resistance to leaf rust in some Egyptian wheat cultivars. Proc. of the $6^{\text {th }}$ Congress of the Egyptian Phytopathological Soci., 1:77- 97.

Nazim, M., M.A. Awad, O.A. Boulot, S.A. Abu El-Naga, I. Abdel-Hamid (2001). Durable resistance to stem rust in 
some Egyptian wheat varieties. Minufiya J. Agric. Res., 26(6): 1485-1499.

Ochoa, J. and J.E. Parlevliet (2007). Effect of partial resistance to barley leaf rust, Puccinia hordei on the yield of three barley cultivars. Euphytica, 153:309-312.

OGGG. (2008). Official Grain Grading Guide. Determining test weight. Industry Services - ISO 9001:2008, ISSN 17045118, Canada.

Omara, R.I.N. (2013). Identification of Wheat Leaf Rust Resistant Genes in Some Newly-Developed Egyptian Wheat Cultivars. Ph.D. Thesis, Plant Pathol., Cairo Univ., $155 p_{p}$.

Pandey, H.N., T.C.M. Menon and M.V. Rao (1989). A simple formula for calculating area under disease progress curve. Rachis, 8(2):38-39.

Peterson, R.F., A.B. Campbell and A.E. Hamah (1948). A diagrammatic scale for estimating rust intensity on leaves and stems of cereal. Can. J. Res., 60:496500.

Peturson, B., Margaret, A. Newton and G.O. Whiteside (1945). The effect of leaf rust on the yield and quality of wheat. Can. J. Res., 23c(4):105-114.

Putnik-Deliã, M. (2008). Resistance of some wheat genotypes to Puccinia triticina. Proc. Nat. Sci. Matica Srpska Novi Sad, 115:51-57.

Sallam, I., M. Abd El-Magid, N. Hegazy and W. Abou Zaid (1995). Effect of packaging and storage on bread containing additives to retard stalling. Egypt. J. Food Sci., 23(1): 133-145.
Singh, R.P., J. Huerta-Espino, W. Pfeiffer and P. Figueroa-Lopez (2004). Occurrence and impact of a new leaf rust race on durum wheat in northwestern Mexico from 2001 to 2003. Plant Dis., 88:703-708.

Singh, R.P., J. Huerta-Espino and H.M. William (2005). Genetics and breeding for durable resistance to leaf and stripe rusts in wheat. Turk. J. Agric., 29:121-127.

Singh, R.P., T.S. Pyne, P. Figueroa and S. Valeza (1991). Comparison of the effect of leaf rust on grain yield of resistant, partially resistant and susceptible spring wheat cultivars. Amer. J. Alter. Agri., 6:115-121.

Stakman, E.C., D.M. Stewart and W.Q. Loegering (1962). Identification of physiologic races of Puccinia graminis tritici. ARS. USDA, Agric. Res. Serv. Bull., E-617. 53pp.

Uhlen, A.K., S. Sahlstrom, E.M. Magnus, E.M. Faergestad, J.A. Dieseth and K. Ringlud (2004). Influence of genotype and protein content on the baking quality of health bread. J. Sci. Food Agric. 84:887-894.

Van der Plank, T.E. (1963). Plant Diseases: Epidemics and Control. Academic Press. New York, 349p

Wang, C.S., L.J. Qi, Y.J. Rong, L. Jun and W.F. Rong (2004). Effects of prevail wheat stripe rust races on yield of new wheat cultivars. Acta Phytophylacica Sinica, 31(2):121-126. 
تأثثر الاصابة بمرض صدأ الاوراق على الانتاجية والصفات التكنولوجية لحبوب بعض أصناف القمح المصرية

رفاعى جمعه على (1) ، رضا ابراهيم عمارة(2) ، زينب عباس على (1) (1) قسم بحوث تكنولوجيا الححاصيل الحقلية - معهد بحوث تكنولوجيا الأغذية - مركز البحوث الزراعيه

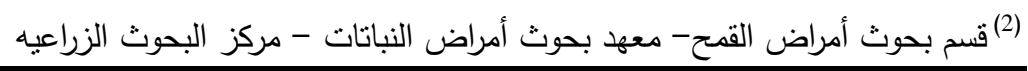

الملخص العربي

بعتبر مرض صدأ الاوراق المتسبب عن الفطر بكسينيا ترتيسينا من أهم أمراض القمح في مصر والعالم. وقد أجريت هذة

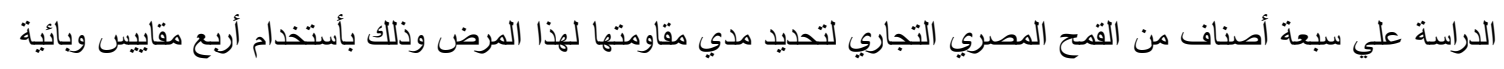

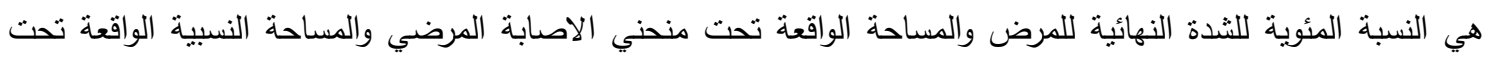

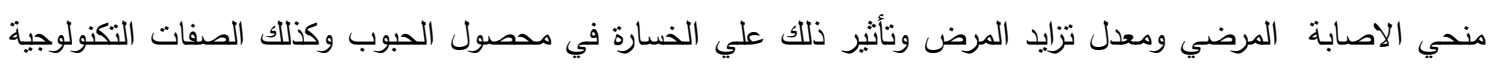
لحبوب تلك الأصناف. حيث سجلت الأصناف جميزه 7 وجميزة 11 و سدس الاصنية 1 أعلي نسب مئوية في الثدة المرضية النهائية

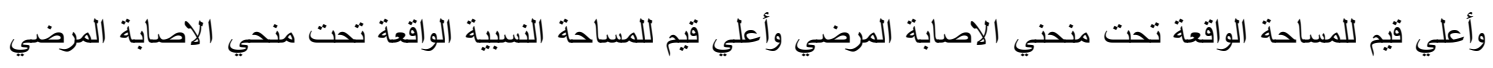

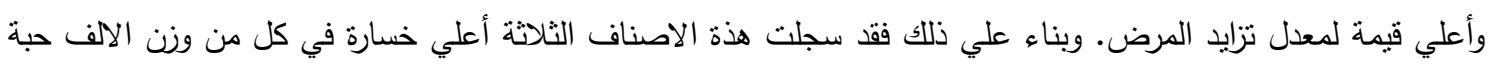
(بالجرام) وكمية المحصول بالنسبة للفدان (بالاردب) مما ادي الي خسارة القاب القتصادية عالية مقدرة بالعائد علي المزارع بالجنية

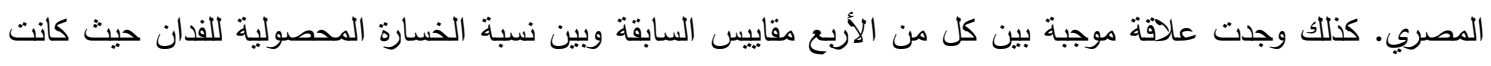

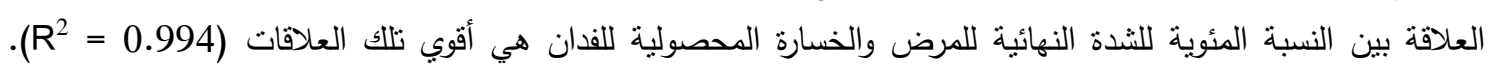

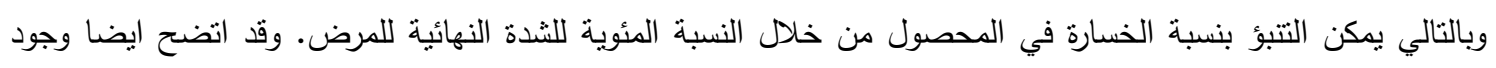
علاقة سالبة بين النسبة المئوية للثدة النهائية للمرض وبين كل من وزن الالف حبة (بالجرام) ومحصول الفدان (بالاردب)

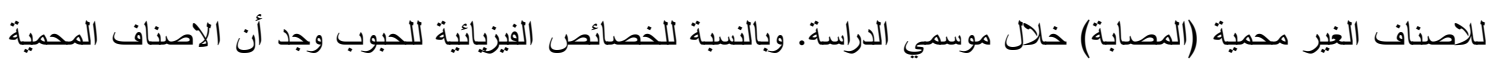

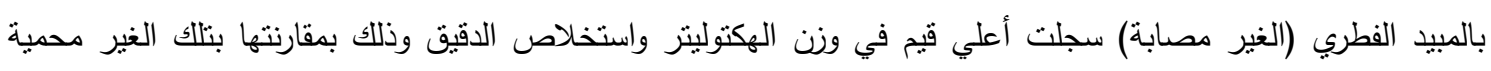
(المصابة) • وعلي الجانب الاخر سجلت الاصناف المصابة قيم عالية نسبيا من البروتين والرماد بمقارنتها بالأصناف الغير مصابة. وايضا بالنسبة لاختبارات الفارينوجراف تحسنت صفات العجين تحسن طفيف في جميع الأصناف المختبرة بمقارنتها

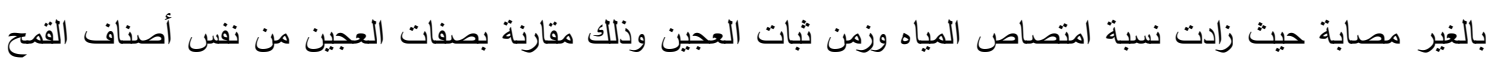

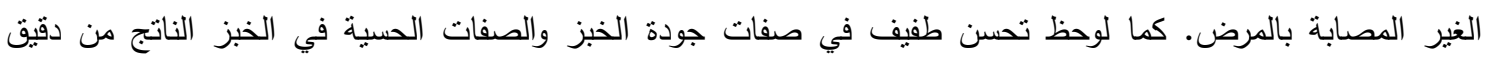

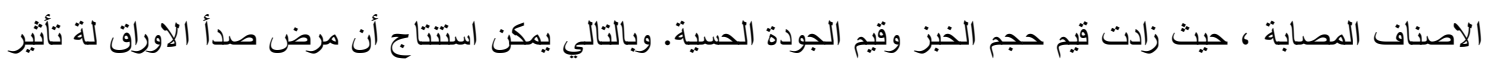
سلبي واضح علي محصول الحبوب الناتج للأصناف تحت الدراسة كما ونوعا. 
Ali, et al., 